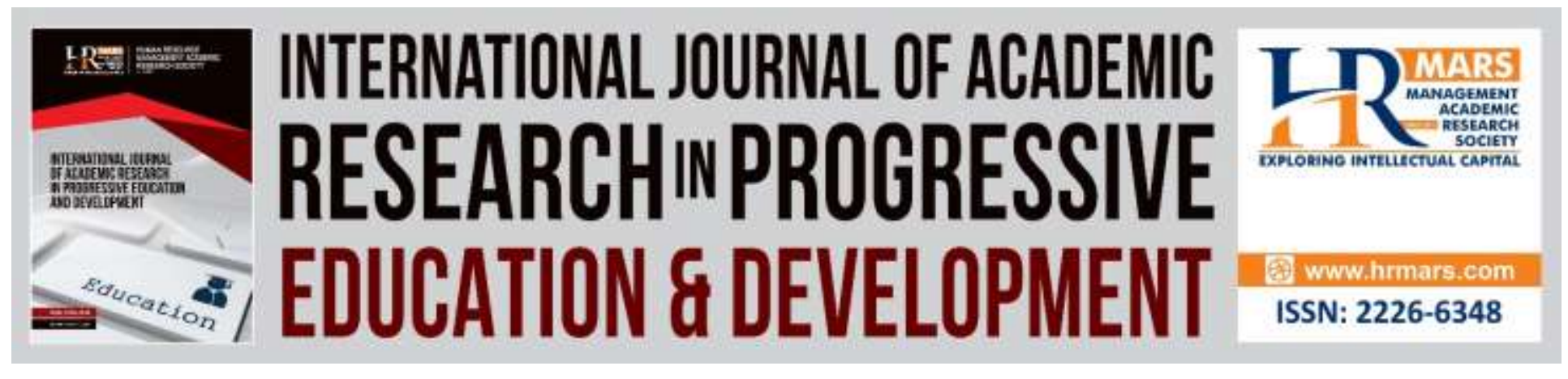

\title{
Neuro-linguistic Programming Modelling: Learning Strategies Used by High Achieving Students in UKM
}

\author{
M. Azwan Yusoff, Aidah A. Karim, H. Norman
}

To Link this Article: http://dx.doi.org/10.6007/IJARPED/v8-i4/6562

DOI:10.6007/IJARPED/v8-i4/6562

Received: 13 October 2019, Revised: 29 October 2019, Accepted: 14 November 2019

Published Online: 30 November 2019

In-Text Citation: (Yusoff, Karim, \& Norman, 2019)

To Cite this Article: Yusoff, M. A., Karim, A. A., Norman, H. (2019). Neuro-linguistic Programming Modelling: Learning Strategies Used by High Achieving students in UKM . International Journal of Academic Research in Progressive Education and Development, 8(4), 429-435.

Copyright: (C) 2019 The Author(s)

Published by Human Resource Management Academic Research Society (www.hrmars.com)

This article is published under the Creative Commons Attribution (CC BY 4.0) license. Anyone may reproduce, distribute, translate and create derivative works of this article (for both commercial and non-commercial purposes), subject to full attribution to the original publication and authors. The full terms of this license may be seen at: http://creativecommons.org/licences/by/4.0/legalcode

Vol. 8(4) 2019, Pg. 429 - 435

http://hrmars.com/index.php/pages/detail/IJARPED

JOURNAL HOMEPAGE

Full Terms \& Conditions of access and use can be found at http://hrmars.com/index.php/pages/detail/publication-ethics 


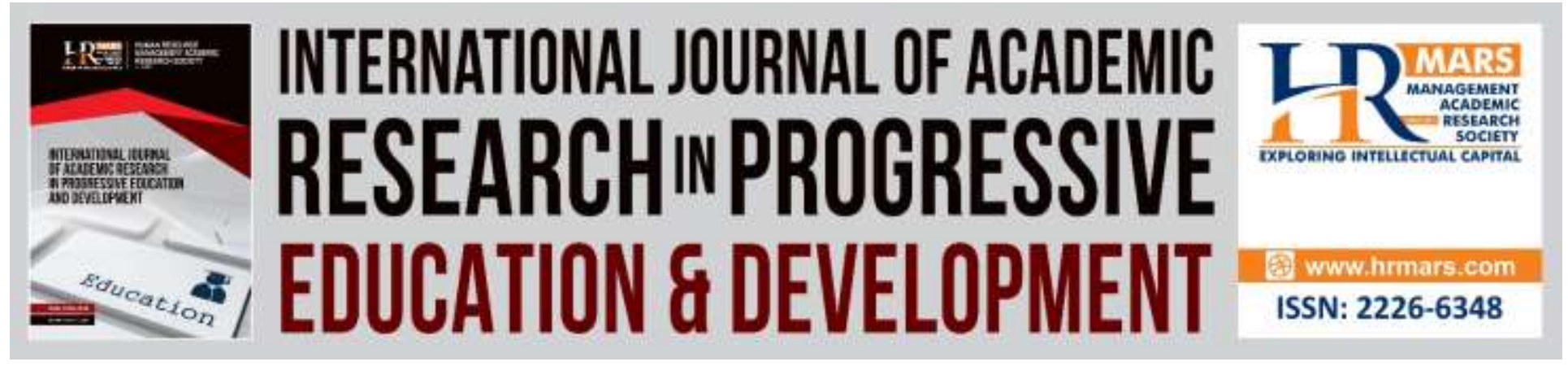

\title{
Neuro-linguistic Programming Modelling: Learning Strategies Used by High Achieving Students in UKM
}

\author{
M. Azwan Yusoff, Aidah A. Karim, H. Norman \\ Faculty of Education, Universiti Kebangsaan Malaysia, UKM Bangi, Selangor, Malaysia \\ Email: azwanukm@Yahoo.Com, eda@ukm.edu.my,helmi.norman@ukm.edu.my
}

\begin{abstract}
Most higher education students are unfamiliar with effective learning strategies that prevented them from achieving good academic result. The purpose of this research is to explore learning strategies of high achieving students. This study employed a qualitative methodology and involved four high achieving students and used semi-structured interviews. This study found ten learning strategies and thirty-seven learning tactics employed by high achieving students. This study found that learning strategies and tactics found in the study suit neuro-linguistic modelling approach. The study suggested that students must be exposed to neuro-linguistic modelling approach early in their university live.
\end{abstract}

Keywords. Learning Strategies, High Achiever, Neuro-linguistic Programming, and Modelling.

\section{Introduction}

Under-achieving students in higher education often do not understand and apply effective learning approaches, which prevented them from achieving good academic result. Muelas and Navarro (2015) stated that low academic achievement was due to weak and ineffective learning strategies. The role of learning styles and students' performance were also highlighted by other studies such as Razak, Zulkifli and Noh (2018); Jaki, Ambun and Yunus (2018); Ishak and Awang (2018); Ph'ng, Ming and Nambiar (2016); Abdullah, Daud, Ariff, \& Shaifuddin, (2018) and Thang et al. (2015). From the past research conducting by Stott and Hobden (2015), they had further identified three learning strategies namely interrogating information, thinking it through, and organizing and linking. They interviewed gifted high achieving student from the rural area school that focused in science learning. There is a gap in this study that should we consider, we decided to conduct the interview with university's high achieving students in learning strategies perspective. Learning strategies are a special kind of procedural knowledge and knowing how to do something (Woolfolk 2016). Despite an increased interest to excel in academic but very few studies focused on developing framework for effective learning strategies in higher learning using Neuro-Linguistic Programming or NLP. Therefore, this study aimed to identify effective learning strategies among high achieved university students in the Malaysian context and further mapped those strategies with NLP approach. 
Vol. 8, No. 4, 2019, E-ISSN: $2226-6348$ @ 2019 HRMARS

\section{Literature Review}

Bodenhamer and Hall (1999) explains that Neuro-linguistic Programming or NLP is divided into three main components: neuro $(\mathrm{N})$, linguistic $(\mathrm{L})$ and programming $(\mathrm{P})$. Neuro refers to our mind and how it processes information and codes it as memory. Linguistic means that, through language and communication structures, neural processes of the mind come coded, organized and given significance. Programming refers to our ability to organize these parts (sights, sounds, feelings, smells, tastes) in our mind-body organism so that we can produce our desired results. Using NLP theory, researchers performs NLP modeling techniques on outstanding students which to explore and elicit their learning strategies. Researchers can more clearly identify the factors of excellence and reflection in their minds during learning activities or actions to be taken (Bandler \& Grinder 1975; Kudliskis 2013; lyem, Ozturk, Yildiz, 2018).

"NLP studies brilliance and quality, bringing outstanding results to individuals and organizations. The techniques can be demonstrated to others so that they can also achieve the same results. This is called modeling."(O'connor, 2001). "The NLP's primary approach was the modeling of efficient behaviors and cognitive processes. The NLP modeling method includes the analysis of linguistic patterns and non-verbal communication in the way that the brain operates. The results of this analysis are then used step-by-step strategies or programs to transfer the skills into other individuals and application fields"(Dilts 1998). From the past NLP research, NLP modelling techniques that will establish positive effects and improve the performance of athletes in the kinesthetic domain by stimulating visual and auditory channels (Grosu et al. 2014). NLP modelling techniques was used which involving learning modalities such as visual, auditory, kinesthetic ("saw," "heard," "felt") (Dilts 1998; Grosu et al. 2014). NLP modelling techniques comes up with questions like how does it look, sound and feel as well as how students learn in specific ways and the secret that the students do every day in their life.

\section{Methodology}

A qualitative methodology has been used for this research. This research explored narratives of learning strategies produced by four high achieving students in one public university in Malaysia. The high achievers from this research context was students that won the Royal Education Award at the university convocation ceremony. This award is the highest achievement awarded by the university to students who excelled in academic, leadership, exemplary character and commitment to the society. The students must obtain at least a Pass with Honors (with distinction) with a final CGPA of 3.7 in the final semester. The students came from Islamic Studies, Social Science \& Humanities, Economy and Management, and Medicine.

There are two types of instruments used in this study, the interview protocol and document analysis. For data collection, we prepared semi structured interviews questions based on learning strategies literature. In addition, documents that we used was online and offline material such as articles related and YouTube interviews conducted by UKM. Bogdan and Bilken (2003) stated that data are rarely validated with one method, but several validation techniques. Data obtained from one source may not be sufficient for this study, so researchers use the triangulation method. The diversity of these sources of knowledge can make this study rich in diverse sources of 
insights. Triangulate various sources of information by analyzing evidence from sources to create a coherent explanation of the issues. Another validity strategy that we use was member checking. Member checking is to determine the accuracy of the qualitative findings by taking specific themes back to high achievers and determining whether the high achievers believe that they are correct (Creswell \& Creswell, 2018). Narratives of learning strategies by high achievers were recorded and transcribed. Transcript was analyzed using thematic analysis which generating initial codes and naming themes were most challenging and complicated tasks (Braun \& Clarke, 2006).

\section{Result}

The result showed ten learning strategies that used by high achieving students. The learning strategies are visualization, goals, attitude, emotional intelligence, information technology, time management, learning practices, note, memorize and examination. Besides, we identified thirty seven of associated tactics that characterized high achievers. All ten learning strategies and thirty seven tactics can be seen in the table 2 below.

Table 1. Ten learning strategies that used by high achievers.

\begin{tabular}{|c|c|}
\hline $\begin{array}{l}\text { Learning } \\
\text { Strategies }\end{array}$ & Tactics \\
\hline 1.Visualization & $\begin{array}{l}\text { a. learning } \\
\text { b. idol } \\
\text { c. motivational words }\end{array}$ \\
\hline 2.Goals & $\begin{array}{l}\text { a. the purpose of the study } \\
\text { b. the goal of socialization } \\
\text { c. career goal }\end{array}$ \\
\hline 3. Attitude & $\begin{array}{l}\text { a. conscious } \\
\text { b. opportunistic } \\
\text { c. confident } \\
\text { d. hard work } \\
\text { e. fast } \\
\text { f. spiritual }\end{array}$ \\
\hline $\begin{array}{l}\text { 4. Emotional } \\
\text { Intelligence }\end{array}$ & $\begin{array}{l}\text { a. identify your emotions } \\
\text { b. control your emotions } \\
\text { c. recognize the emotions of } \\
\text { others } \\
\text { d. build relationship } \\
\text { d. motivate oneself }\end{array}$ \\
\hline $\begin{array}{l}\text { 5. Information } \\
\text { Technology }\end{array}$ & $\begin{array}{l}\text { a. spesific website } \\
\text { b. internet video } \\
\text { c. internet search }\end{array}$ \\
\hline
\end{tabular}


Vol. 8, No. 4, 2019, E-ISSN: 2226-6348 @ 2019 HRMARS

\begin{tabular}{|c|c|}
\hline & d. social networks \\
\hline $\begin{array}{l}\text { 6. Time } \\
\text { Management }\end{array}$ & $\begin{array}{l}\text { a. planning activities } \\
\text { b. planning priorities }\end{array}$ \\
\hline 7. Learning Practices & $\begin{array}{l}\text { a. learning goals } \\
\text { b. learning styles } \\
\text { c. active learning } \\
\text { d. learning in class } \\
\text { e. learning environment }\end{array}$ \\
\hline 8. Note & $\begin{array}{l}\text { a. practice of writing notes } \\
\text { b. note style } \\
\text { c. visual note }\end{array}$ \\
\hline 9. Memorize & $\begin{array}{l}\text { a. acronym } \\
\text { b. loci } \\
\text { c. mnemonic }\end{array}$ \\
\hline 10. Examination & $\begin{array}{l}\text { a. before the exam } \\
\text { b. during the exam } \\
\text { c. after the exam }\end{array}$ \\
\hline
\end{tabular}

\section{Discussion}

From the previous research, Stott and Hobden (2015) reported three learning strategies namely interrogating information, thinking it through, and organizing and linking. This research contribute ten learning strategies that influence students in learning and the students will have as much mileage out of the learning strategies theme as they could. The advantage researchers by using NLP modeling techniques was emerging of surprising code that the code on unexpected findings and could not be anticipated before the research started (Creswell, \& Creswell, 2018). The theme comprises surprising code are visualization, memorize and emotional intelligence.

Visualization is the process of making pictures or movies in our mind (Wong 2009). Visualization is a strong visual encoding memory instrument and can generate a powerful visual picture that can be retrieved from long-term memory. Information presented in visual or graphical form, such as a picture or a diagram, is often more easy for many students especially for visual learners to apply this strategy. In this research, visualization strategy can make high achieving students feel motivation before they study and remember what they had learned.

Besides visualization strategy that makes high achievers remember what they had learned. They also have strategy that called memorize, which uses visualization in specific way. Memorize strategy comprises three tactics namely acronym, loci and mnemonic, which make they remember long lasting than others. Through mnemonic tactic, mnemonic is a memory system that is a bridge for you to retrieve long-term memory information (Wong, 2009). High achievers have developed their own way of remembering something but the other doesn't understand. They also include some visual, sound and emotion in it to help them remember better. 
Emotional intelligence strategy consists five major tactics namely identify your emotions or selfawareness, control your emotions or managing emotions, recognize the emotions of others, build relationship and motivate yourself. Emotional intelligence (EI) was established by Danial Goleman and Goleman (1997) pointed out that intelligence quotient (IQ) contributes only $20 \%$ to the success of a lifetime and the rest $80 \%$ comes from emotional intelligence (EI). Researchers have successfully discovered emotional intelligence, same as five of Daniel Goldman's (EI) components using NLP modeling techniques. Researchers also believe that besides high achiever's IQ, the high archiver also had emotional intelligence to excel in academic.

The future study of this research is how to disseminate this learning strategies to our students with better understanding that can benefit for future generation. Furthermore, modeling the higher achiever might be to view from different perspectives for next research such as critical thinking, problem solving, and emotional experiences.

\section{Acknowledgement}

This work was supported by UKM grants PP-FPEND-2019 and GG-2019-067

\section{References}

Abdullah, C. Z. H., Daud, S. C., Ariff, N. Z. Z. M., \& Shaifuddin, N. (2018). Bibliographic Control and Resource Description Access Standard in Malaysia. International Journal of Academic Research in Progressive Education and Development, 7(3), 96-102

Bandler, R., and Grinder, J. (1975). The Structure of Magic, Volume I: A Book About Language and Therapy. Palo Alto CA: Science \& Behavior Books.

Bodenhamer, B. G, and Hall, L. M. (1999). The User's Manual For the Brain : The Complete Manual For Neuro-Linguistic Programming Practitioner Certification. Crown House Publishing.

Bogdan, R. C., and Bilken, S. K. (2003). Qualitative Research for Education. An Introduction to Theories and Methods. 4th ed. Pearson Education Group.

Braun, V., and Clarke, V. (2006). "Using Thematic Analysis in Psychology." Qualitative Research in Psychology 3(May 2015): 77-101.

Creswell, John, W., and Creswell, J. D. (2018). Research Design : Qualitative, Quantitative and Mixed Methods Approaches. Sage Publications Inc.

Dilts, R. (1998). Modeling with NLP. Meta Publications, Capitola,CA.

Goleman, D. (1997). Emotional Intelligence: Why It Can Matter More Than IQ. Bantam Books.

Grosu, Florina, E., Grosu, T., Preja, T., and Balint, B. (2014). “Neuro-Linguistic Programming Based on the Concept of Modelling." Procedia - Social and Behavioral Sciences 116: 3693-99.

Ishak, N., \& Awang, M. M. (2017). The relationship of student learning styles and achievement in history subject. The International Journal of Social Sciences and Humanities Invention 4(3). 3372-3377

Jaki, V. A., \& Yunus, M. M. (2018). Language learning styles among TESL undergraduate students in Universiti Kebangsaan Malaysia from different gender groups. The Asian EFL Journal. 20(8). 76-89

Kudliskis, V. (2013). “Neuro-Linguistic Programming and Altered States : Encouraging Preparation 
for Learning in the Classroom for Students with Special Educational Needs." British Journal of Special Education 40(2).

Ph'ng, M. L., Ming, T. S., \& Nambiar, R. M. K. (2016). Match or mismatch: Teaching styles and learning styles in an ESP classroom. The Social Sciences. 11 (12). 2977-2982

Muelas, A., and Navarro, E. (2015). "Learning Strategies and Academic Achievement." Procedia Social and Behavioral Sciences 165: 217-21.

http://dx.doi.org/10.1016/j.sbspro.2014.12.625.

O'connor, Joseph. (2001). The NLP Workbook: The Practical Guidebook to Achieving the Results You Want. Harper Collins.

Razak, K. A., Zulkifli, H., \& Noh, M. A. C. (2018). Jour of Adv Research in Dynamical \& Control Systems, 10 (12). 1366-1370

Stott, Angela, and Hobden, P. A. (2015). "Effective Learning: A Case Study of the Learning Strategies Used by a Gifted High Achiever in Learning Science." Gifted Child Quarterly 1(12).

Thang, S. M., Nambiar, R. M. K., Wong, F. F., Jaafar, N. M. \& Amir, Z. (2015). A clamour for more technology in universities: What does an investigation into the ICT use and learning styles of Malaysian digital natives tell us. Asia-Pacific Edu Res. 24 (2). 353-361

Wong, L. (2009). Essential Study Skills. Houghton Mifflin Company.

Woolfolk, A. (2016). Educational Psychology. Pearson Education.

Iyem, C., Ozturk, D. G., Yıldız, F. Z. (2018). Clustering and Clustering Potential in TR 32 Regions Province, International Journal of Academic Research in Accounting, Finance and Management Sciences 8 (3): 336- 345. 